\title{
Et barn er født...
}

Underet har skjedd til alle tider - i dag som for to tusen år siden. Og når barnet er kommet til verden, skal det stelles, mates, bysses og lekes med - for at det skal ha optimale muligheter for vekst og utvikling. Major Neumann-Neurode var før første verdenskrig gymlærer i den tyske hær. Han fant at det var få av rekruttene som hadde harmonisk utviklet kropp og god holdning og at dette var vanskelig å rette opp. Defektene kunne ha vært unngått dersom de unge på et tidligere tidspunkt var kommet under kontroll og kyndig gymnastisk ledelse. Han utarbeidet derfor et gymnastikksystem spesielt beregnet på barn, senere på spedbarn.

I Tidsskriftet nr. 23/1939 presenterer frk. Mossige metoden (Tidsskr Nor Lægeforen 1939; 59: 1236-42). Hun går nøye gjennom resultatene og oppsummerer til slutt den medisinske nytte.

\section{Spebarnsgymnastikk.}

Av frk. Hanne Mossige, Oslo.

Innledning til demonstrasjon i Norsk pediatrisk selskap, mai 1939.

I hvilke tilfelle spebarnsgymnastikk med fordel kan anvendes av lægen som behandlingsmåte, blir selvfølgelig et spørsmål av rent medisinsk art. Jeg vil bare tillate mig kort å regne op nogen av de tilfelle hvor jeg under min utdannelse har sett at spebarnsgymnastikken er blitt anvendt. For det første på dorske, sent utviklede og nærvøse barn. Dernæst på barn med feil i knokkelbygningen, barn med øket, minsket eller manglende tonus og med skjevheter i hvirvelsøilen samt barn med treg mave, og endelig som efterbehandling for forskjellige sykdommer som rakitt, poliomyelitt o.s.v.
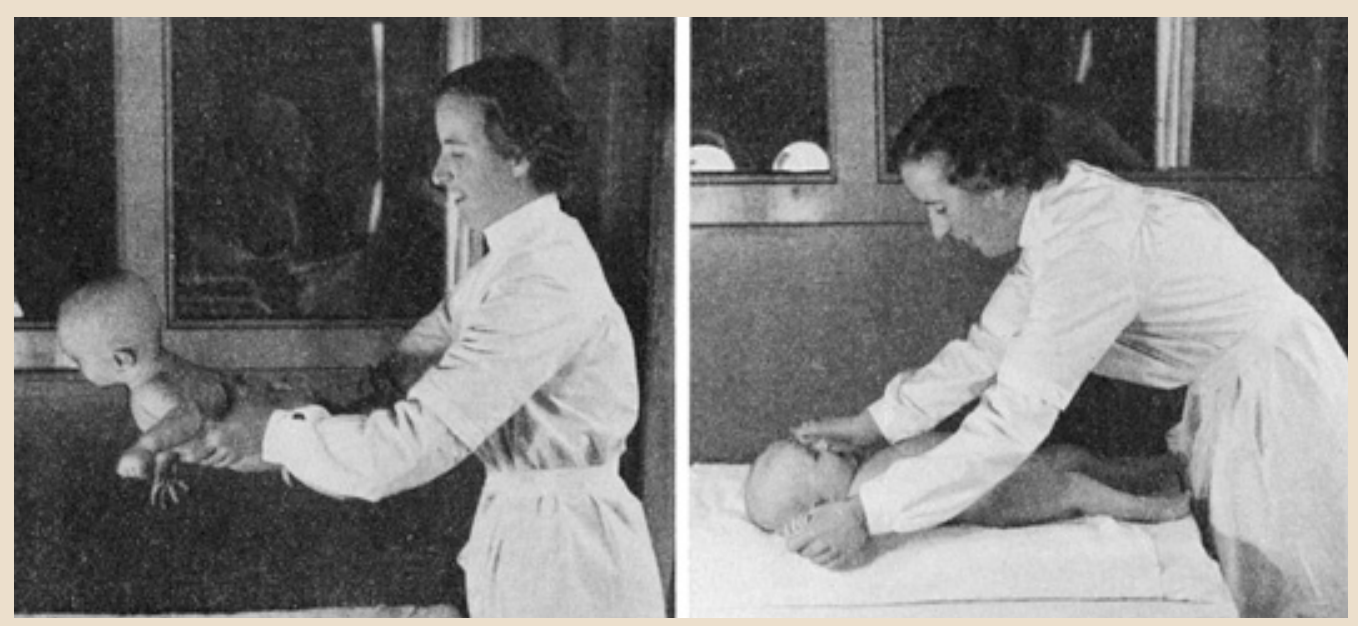